Article

\title{
Combined Use of $S$. pombe and L. thermotolerans in Winemaking. Beneficial Effects Determined through the Study of Wines' Analytical Characteristics
}

\author{
Ángel Benito, Fernando Calderón and Santiago Benito * \\ Chemistry and Food Technology Department, Polytechnic University of Madrid, Avenida Complutense S/N, \\ 28040 Madrid, Spain; angel@urbinavinos.com (A.B.); fernando.calderon@upm.es (F.C.) \\ * Correspondence: santiago.benito@upm.es; Tel.: +34-91-3363-710 \\ Academic Editor: Derek J. McPhee \\ Received: 3 November 2016; Accepted: 7 December 2016; Published: 18 December 2016
}

\begin{abstract}
The most common way to produce red wine is through the use of Saccharomyces cerevisiae strains for alcoholic fermentation and lactic acid bacteria for malolactic fermentation. This traditional winemaking methodology produces microbiologically stable red wines. However, under specific conditions off-flavours can occur, wine quality can suffer and human health problems are possible, especially after the second fermentation by the lactic acid bacteria. In warm countries, problems during the malolactic fermentation arise because of the high $\mathrm{pH}$ of the must, which makes it very difficult to properly control the process. Under such conditions, wines with high acetic acid and histamine concentrations are commonly produced. This study investigates a recent red wine-making technology that uses a combination of Lachancea thermotolerans and Schizosaccharomyces pombe as an alternative to the conventional malolactic fermentation. This work studies new parameters such as aroma compounds, amino acids, ethanol index and sensory evaluation. Schizosaccharomyces pombe totally consumes malic acid while Lachancea thermotolerans produces lactic acid, avoiding excessive deacidification of musts with low acidity in warm viticulture areas. This methodology also reduces the malolactic fermentation hazards in wines with low acidity. The main products are wines that contain less acetic acid, less biogenic amines and precursors and less ethyl carbamate precursors than the traditional wines produced via conventional fermentation techniques.
\end{abstract}

Keywords: Schizosaccharomyces pombe; Lachancea thermotolerans; pyruvic acid; malic acid; lactic acid; urea; food safety; amino acids; winemaking

\section{Introduction}

It is currently assumed that regular alcoholic fermentation and malolactic fermentation is the only way to microbiologically stabilize a red wine before bottling. However, Pasteur considered malolactic fermentation as a wine problem during the first studies of wine microbiology because he considered lactic acid bacteria to be wine spoilage microorganisms. Many research groups are now paying attention to the oenological applications of non-Saccharomyces yeast strains to improve wine quality [1-6]. Some of the most studied non-Saccharomyces yeast species in winemaking are Torulaspora delbrueckii [7,8], Kloeckera apiculata [9], Hanseniaspora uvarum [10], Hanseniaspora vineae [11], Candida zemplinina [12], Candida pulcherrima [13], Schizosaccharomyces pombe [14], Hansenula anomala [15] and Lachancea thermotolerans [16,17]. Most of these studies report that sequential inoculation of a non-Saccharomyces and a Saccharomyces cerevisiae strain is the best option.

S. pombe has traditionally been used for deacidification due to its ability to convert the harsh tasting L-malic acid into ethanol, making very acidic wines smoother [18-20]. However, organisms of the genus Schizosaccharomyces are also used in winemaking for many other purposes. One new 
application exploits their ability for higher polysaccharide release during fermentation and ageing over lees $[4,21,22]$. Another one is their use to decrease gluconic acid concentration in wines from rotten grapes [23-27], as well as color improvement of red wines through their ability for enhanced formation of highly stable pigments such as the vitisins and pyranoanthocyanin [28-30]. Finally, from a food safety viewpoint, the genus Schizosaccharomyces is being used to produce safer wines [31] because it possess urease activity [32] that avoids ethyl carbamate production and reduces the risk of biogenic amine formation by wild-type lactic acid bacteria [33]. Conversely, Lachancea thermotolerans is used in warm regions to produce more acidic wines, with less volatile acidity and higher aroma complexity from low acidic musts [33-36].

The genus S. pombe has not been traditionally used for winemaking due to the occurrence of off-flavours caused by substances such as acetic acid, acetaldehyde, acetoin and ethyl acetate [37-41], which are currently associated with non-selected strains [42]. Recent studies have proven that it is possible to select strains that are appropriate for winemaking [14]. The main problem with such selection processes was the difficulty of isolating a representative number of strains from environmental samples [43], which has caused difficulty until now to obtain collections of representative strains of this genus [44]. Nevertheless, the number of available strains is limited and further selection processes similar to those performed for $S$. cerevisiae for winemaking are required.

This new study combined strains of L. thermotolerans and S. pombe to make wine from a high $\mathrm{pH}$ and high potential alcohol must without using Saccharomyces and lactic acid bacteria, to avoid possible collateral effects from malolactic fermentation. Several parameters such as volatile compounds, amino acids, ethanol index and sensory properties of the wines produced with this new biotechnology were investigated for the first time. Additionally, as in previous studies, acid content, $\mathrm{pH}$, glycerol, urea, alcohol and biogenic amines were also determined.

\section{Results and Discussion}

\subsection{Yeast Population Kinetics}

Figure 1 shows the growth of the different yeast strains during fermentation. In sequential fermentations, inoculated with Saccharomyces cerevisiae 88 or Schizosaccharomyces pombe 4.5, Lachancea thermotolerans CONCERTO ${ }^{\mathrm{TM}}$ started to decline just after the second inoculation, although the $L$. thermotolerans population decrease was more rapid in the presence of $S$. cerevisiae. The progressive disappearance of $L$. thermotolerans could be explained as a result of the presence of another more well-adapted yeast competitor (S. cerevisiae or S. pombe) and an ethanol concentration higher than $9 \% v / v$ by day 6 . L. thermotolerans has been reported to only tolerate up to $9 \% v / v$ ethanol when in a pure culture fermentation [33,34]. This limited alcohol tolerance of L. thermotolerans causes difficulty in the production of a dry red wine in warm regions alone without using a yeast with higher ethanol tolerance in a combined fermentation.
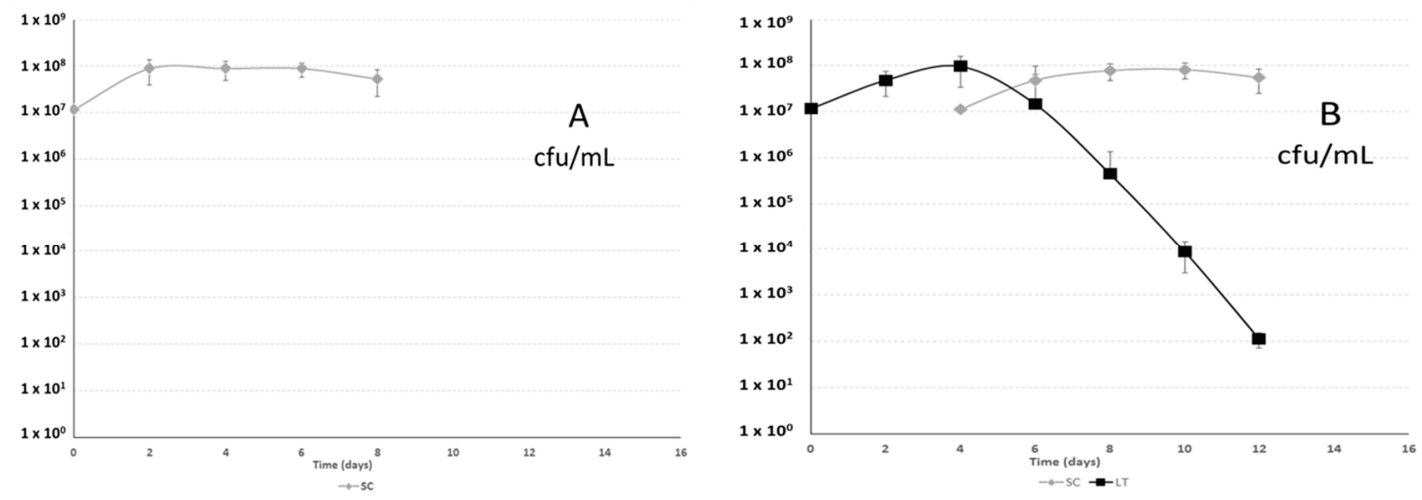

Figure 1. Cont. 

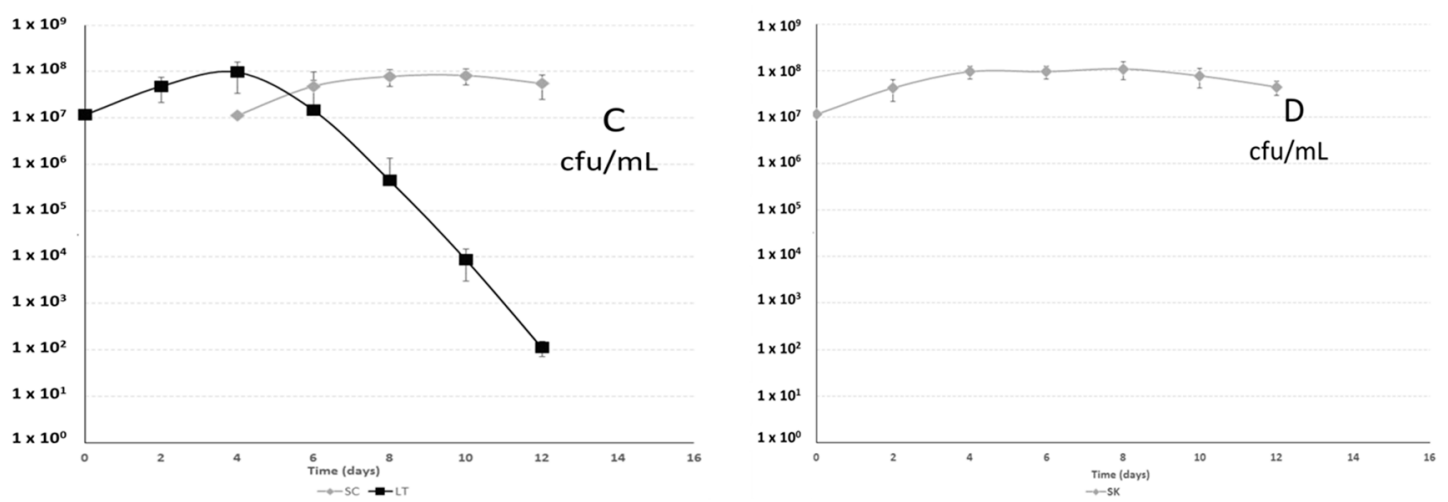

Figure 1. Population development during fermentation of Saccharomyces cerevisiae 88 alone (SC; A), sequential fermentation with Saccharomyces cerevisiae 88 and Lachancea thermotolerans CONCERTO ${ }^{\mathrm{TM}}$ (LT ... SC; B), sequential fermentation with Schizosaccharomyces pombe 4.5 and Lachancea thermotolerans CONCERTO $^{\text {TM }}$ (LT ... SK; C) and Schizosaccharomyces pombe 4.5 alone (SK; D).

\subsection{Sugar Consumption Kinetics}

The consumption kinetics of glucose and fructose were more rapid when S. cerevisiae strain 88 was involved (Figure 2) than when L. thermotolerans and S. pombe were used. The alcoholic fermentation times varied from 8 to 16 days. All alcoholic fermentations finished correctly, reaching concentrations lower than $2 \mathrm{~g} / \mathrm{L}$ of glucose and fructose (Figure 2 and Table 1). Other authors have previously described slower fermentation kinetics for L. thermotolerans $[16,17]$ and S. pombe [38] than for S. cerevisiae. Musts with high sugar contents have been reported to be improperly fermented by L. thermotolerans alone [34].

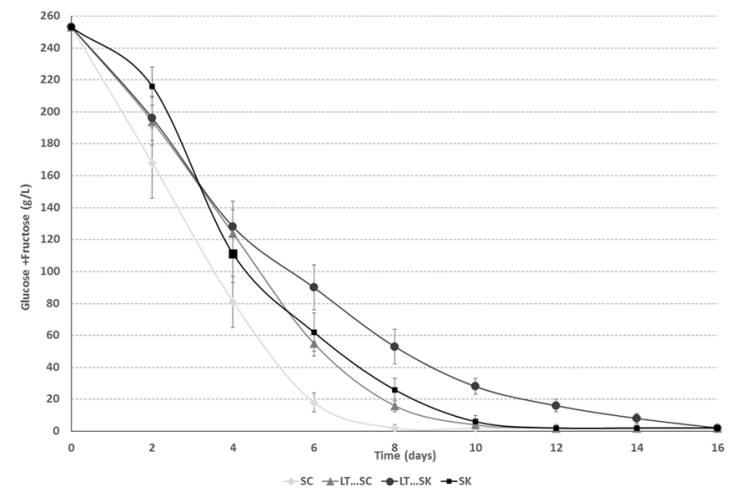

Figure 2. Fermentation kinetics of glucose + fructose for Saccharomyces cerevisiae 88 alone (SC), a sequential fermentation with Saccharomyces cerevisiae 88 and Lachancea thermotolerans CONCERTO ${ }^{\mathrm{TM}}$ (LT ... SC), a sequential fermentation with Schizosaccharomyces pombe 4.5 and Lachancea thermotolerans CONCERTO $^{\text {TM }}$ (LT ... SK) and Schizosaccharomyces pombe 4.5 alone (SK).

\subsection{Acetic Acid}

The maximal final concentration of acetic acid was $0.49 \mathrm{~g} / \mathrm{L}$ for a malolactic fermentation following an alcoholic fermentation by S. cerevisiae in pure culture (Table 1). Alcoholic fermentations alone did not show significant differences, with values of approximately $0.37 \mathrm{~g} / \mathrm{L}$. Previous studies reported the L. thermotolerans produced less acetic acid than S. cerevisiae [36,45]. The genus Schizosaccharomyces has been previously reported as producing more acetic acid than $S$. cerevisiae, with acetic acid concentrations up to $1 \mathrm{~g} / \mathrm{L}$ [29]. However, some S. pombe strains have been recently selected for their low acetic acid production [14,42], and the results for those strains agree with the results obtained in this study. 
Table 1. Final analysis of fermentations: Saccharomyces cerevisiae 88 alone (SC), sequential fermentation with Saccharomyces cerevisiae 88 and Lachancea thermotolerans CONCERTO ${ }^{\mathrm{TM}}$ (LT ... SC), sequential fermentation with Schizosaccharomyces pombe 4.5 and Lachancea thermotolerans CONCERTO ${ }^{\mathrm{TM}}$ (LT ... SK), Schizosaccharomyces pombe 4.5 alone (SK), and fermentations after a malolactic fermentation with Oenococcus oeni 217 (+MLF).

\begin{tabular}{|c|c|c|c|c|c|c|}
\hline Compound/Property & SC & SC + MLF & LT...SC & LT $\cdots$ SC + MLF & LT...SK & SK \\
\hline L-Lactic Acid (g/L) & $0.01 \pm 0.01_{\mathrm{a}}$ & $0.73 \pm 0.06_{b}$ & $2.96 \pm 0.12_{c}$ & $3.71 \pm 0.18_{\mathrm{d}}$ & $3.41 \pm 0.23 \mathrm{~d}$ & $0.02 \pm 0.02 \mathrm{a}$ \\
\hline L-Malic Acid (g/L) & $1.14 \pm 0.03_{\mathrm{b}}$ & $0.01 \pm 0.01 \mathrm{a}$ & $1.10 \pm 0.05_{b}$ & $0.01 \pm 0.01 \mathrm{a}$ & $0.01 \pm 0.01 \mathrm{a}$ & $0.01 \pm 0.01 \mathrm{a}$ \\
\hline Acetic Acid (g/L) & $0.38 \pm 0.02 \mathrm{a}$ & $0.49 \pm 0.04_{\mathrm{b}}$ & $0.35 \pm 0.03 \mathrm{a}$ & $0.43 \pm 0.04_{b}$ & $0.35 \pm 0.04 \mathrm{a}$ & $0.39 \pm 0.02 \mathrm{a}$ \\
\hline Glucose+Fructose (g/L) & $1.55 \pm 0.21_{\mathrm{b}}$ & $0.09 \pm 0.03 \mathrm{a}$ & $1.76 \pm 0.32 \mathrm{~b}$ & $0.14 \pm 0.05_{\mathrm{a}}$ & $1.98 \pm 0.43_{b}$ & $1.72 \pm 0.24_{\mathrm{b}}$ \\
\hline Glycerol (g/L) & $8.88 \pm 0.02 \mathrm{a}$ & $8.92 \pm 0.044_{\mathrm{a}}$ & $9.13 \pm 0.05_{b}$ & $9.11 \pm 0.08_{b}$ & $9.38 \pm 0.06_{c}$ & $9.66 \pm 0.02 \mathrm{~d}$ \\
\hline Urea (mg/L) & $2.62 \pm 0.02 \mathrm{~b}$ & $5.18 \pm 0.08_{\mathrm{c}}$ & $2.58 \pm 0.05_{\mathrm{b}}$ & $5.23 \pm 0.11_{c}$ & $0.14 \pm 0.04 \mathrm{a}$ & $0.12 \pm 0.02 \mathrm{~b}$ \\
\hline Citric Acid (g/L) & $0.18 \pm 0.01_{\mathrm{b}}$ & $0.02 \pm 0.01 \mathrm{a}$ & $0.17 \pm 0.04_{\mathrm{b}}$ & $0.04 \pm 0.03 \mathrm{a}$ & $0.18 \pm 0.03_{b}$ & $0.19 \pm 0.01_{\mathrm{b}}$ \\
\hline Alcohol $(\% v / v)$ & $14.7 \pm 0.0_{\mathrm{d}}$ & $14.7 \pm 0.0_{\mathrm{d}}$ & $14.5 \pm 0.0_{\mathrm{c}}$ & $14.5 \pm 0.0_{c}$ & $14.2 \pm 0.0 \mathrm{a}$ & $14.3 \pm 0.0_{\mathrm{b}}$ \\
\hline $\mathrm{pH}$ & $3.90 \pm 0.02 \mathrm{c}$ & $3.96 \pm 0.03 \mathrm{~d}$ & $3.71 \pm 0.04 \mathrm{a}$ & $3.75 \pm 0.03 \mathrm{a}$ & $3.69 \pm 0.04 \mathrm{a}$ & $4.06 \pm 0.02 \mathrm{~d}$ \\
\hline
\end{tabular}

Results are the mean \pm SD of three replicates. Means in the same row with the same letter are not significantly different $(p<0.05)$.

\subsection{Malic Acid}

Malic acid was completely degraded in all trials with S. pombe (Figure 3 and Table 1) during alcoholic fermentation. The $S$. cerevisiae strain degraded $14 \%$ of the initial malic acid content in the must (Figure 3 and Table 1).

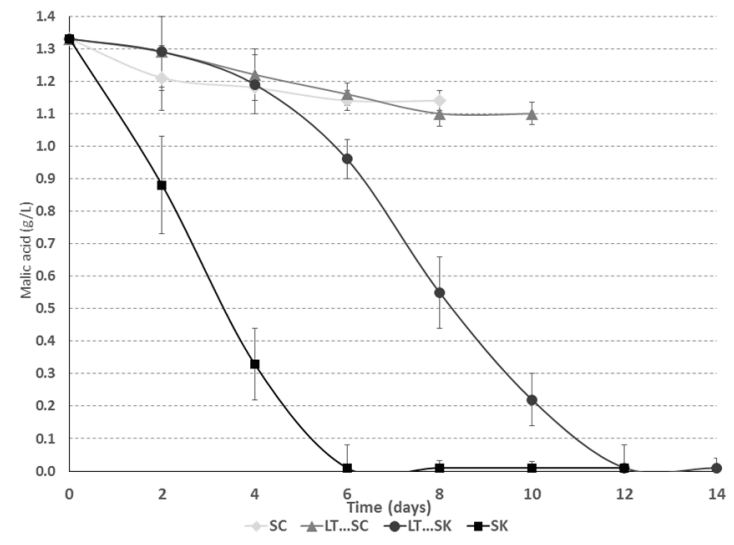

Figure 3. Fermentation kinetics of L-malic acid for Saccharomyces cerevisiae 88 alone (SC), a sequential fermentation with Saccharomyces cerevisiae 88 and Lachancea thermotolerans CONCERTO ${ }^{\mathrm{TM}}$ (LT ... SC), a sequential fermentation with Schizosaccharomyces pombe 4.5 and Lachancea thermotolerans CONCERTO ${ }^{\mathrm{TM}}$ (LT ... SK) and Schizosaccharomyces pombe 4.5 alone (SK).

Several authors have reported similarly high malic acid degradations for yeast in genera other than Schizosaccharomyces, which varied from 10 to $20 \%$ [7,42] or even up to $39 \%$ for specific hybrids [46], but no one has reported the total degradation of malic acid (i.e., 100\%) by those genera. The malic acid reduction clearly affected the final $\mathrm{pH}$ value of the fermentations (Table 1) because $S$. pombe fermentations had a final $\mathrm{pH}$ greater than 4. O. oeni metabolized malic acid to lactic acid in a malolactic fermentation (Table 1).

\subsection{L-Lactic Acid}

Fermentations involving $L$. thermotolerans produced L-lactic acid during alcoholic fermentation (Figure 4; Table 1). The final concentration of L-lactic acid produced by L. thermotolerans in this study varied from 2.96 to $3.41 \mathrm{~g} / \mathrm{L}$ (Table 1), which reduced the final $\mathrm{pH}$ (Table 1). Previous studies have reported significant acidification from L-lactic acid, varying from $0.22 \mathrm{~g} / \mathrm{L}$ to $6.38 \mathrm{~g} / \mathrm{L}$ when mixed cultures of Lachancea thermotolerans were used with the main objective of increasing the acidity of the 
must $[17,33,36]$. Experiments involving malolactic fermentations showed an increase in L-lactic acid of approximately $0.73 \mathrm{~g} / \mathrm{L}$ (Table 1). These final L-lactic acid concentration levels were significantly lower than the ones obtained using $L$. thermotolerans for the studied must. This phenomenon could be explained in that the initial level of malic acid of $1.33 \mathrm{~g} / \mathrm{L}$ was low compared to northern viticulture regions that produce a must with higher initial malic acid concentration.

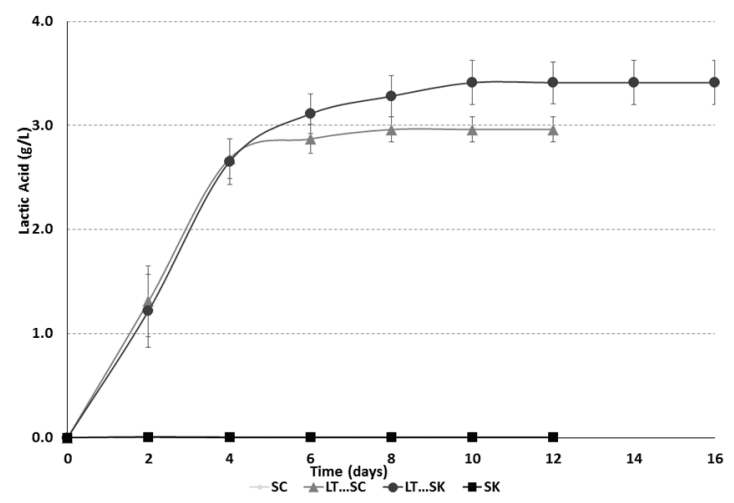

Figure 4. Fermentation kinetics of L-lactic acid for Saccharomyces cerevisiae 88 alone (SC), a sequential fermentation with Saccharomyces cerevisiae 88 and Lachancea thermotolerans CONCERTO ${ }^{\mathrm{TM}}$ (LT ... SC), a sequential fermentation with Schizosaccharomyces pombe 4.5 and Lachancea thermotolerans CONCERTO ${ }^{\mathrm{TM}}$ (LT ... SK) and Schizosaccharomyces pombe 4.5 alone (SK).

\subsection{Pyruvic Acid}

All fermentations involving $S$. pombe produced a higher pyruvic acid concentration than the others (Figure 5). The maximum values were obtained during the first days of alcoholic fermentation (Figure 5), except for sequential fermentation with L. thermotolerans and S. pombe, in which the maximum concentration was reached at day 8 . A pure culture of $S$. pombe produced a maximum pyruvic acid concentration of $318 \mathrm{mg} / \mathrm{L}$ after $96 \mathrm{~h}$ of fermentation. Other authors have reported higher values of up to $487 \mathrm{mg} / \mathrm{L}$ for some selected S.pombe strains in pure culture [42]. Specific S. cerevisiae strains have also been reported to produce a maximum pyruvic acid concentration as high as $150 \mathrm{mg} / \mathrm{L}$ [47], which is higher than for S. cerevisiae strain 88. Greater pyruvic acid formation could be related to the higher colour intensity observed in this study for $S$. pombe fermentations because this compound is related to the formation of highly stable coloured pigments such as vitisin A $[17,30,48]$.

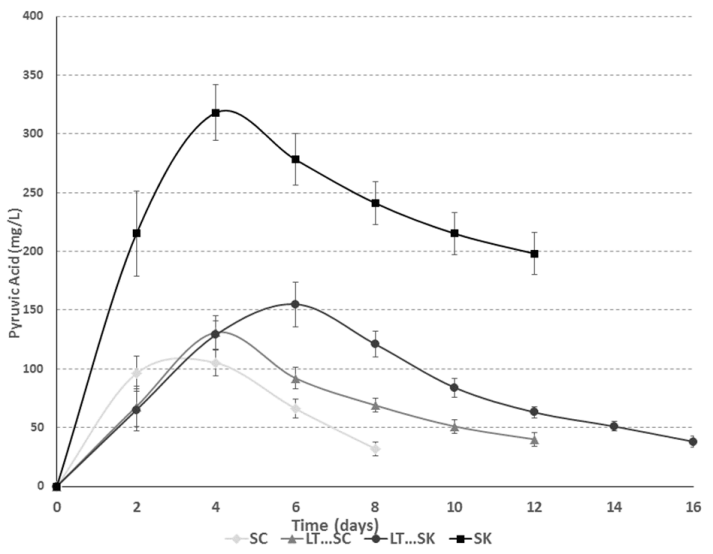

Figure 5. Fermentation kinetics of pyruvic acid for Saccharomyces cerevisiae 88 alone (SC), sequential fermentation with Saccharomyces cerevisiae 88 and Lachancea thermotolerans CONCERTO ${ }^{\mathrm{TM}}$ (LT ... SC), a sequential fermentation with Schizosaccharomyces pombe 4.5 and Lachancea thermotolerans CONCERTO ${ }^{\mathrm{TM}}$ (LT ... SK) and Schizosaccharomyces pombe 4.5 alone (SK). 


\subsection{Glycerol}

The genera Schizosaccharomyces and Lachancea have been described as higher glycerol producers than the genus Saccharomyces $[17,36,45]$. The final levels of glycerol varied from $8.88 \mathrm{~g} / \mathrm{L}$ to $9.66 \mathrm{~g} / \mathrm{L}$ (Table 1). S. pombe produced the highest concentration (Table 1). A high glycerol content has been described as one of the main contributions of non-Saccharomyces strains to wine quality $[1,49]$. Nevertheless, other authors have reported that species such as Candida stellata could effectively produce high concentrations of glycerol of up to $14 \mathrm{~g} / \mathrm{L}$ [1].

\subsection{Ethanol}

The ethanol levels varied from 14.22 to 14.78 ( $\% v / v$ ) (Table 1$)$. Other authors have reported that S. pombe is highly resistant to ethanol stress conditions [50]. Sugar metabolism can be used to synthetize compounds other than ethanol, such as glycerol or pyruvic acid, or to increase the biomass of the yeast $[51,52]$. The results show that fermentations involving L. thermotolerans and S. pombe produced lower ethanol levels than S. cerevisiae. These data are in accord with other authors who confirmed that some non-Saccharomyces yeasts produced lower ethanol yields than Saccharomyces [27,53-56]. Previous studies have shown similar results for L. thermotolerans [36] and S. pombe [53]. Nevertheless, the differences (Table 1 ) were approximately $0.56 \%(v / v)$. Some authors have recently reported more significant ethanol reductions greater than $1 \%(v / v)$ using non-Saccharomyces strains, which may be related to specific conditions of high aeration $[57,58]$ or via the use of glucose oxidase and catalase [59].

\subsection{Urea}

The final concentration of urea in the completed alcoholic fermentations was lower in fermentations involving S. pombe, with values less than $0.2 \mathrm{mg} / \mathrm{L}$ (Table 1). This effect was attributed to the enzymatic capacity of Schizosaccharomyces to produce urease [32,60], the activity of which has been proposed as a means of reducing the hazard of ethyl carbamate formation (one of the most toxic compounds reported in wine) $[14,31]$ in winemaking because urease eliminates urea, the main precursor of ethyl carbamate. This factor is becoming increasingly important because ethyl carbamate is a known carcinogen that is present in a variety of fermented foods [61]. Some countries such as the USA, Japan and Canada have established legal limits.

\subsection{Citric Acid}

No statistical differences in citric acid were observed during any alcoholic fermentation (Table 1). However, in an experiment in which O. oeni was inoculated after an alcoholic fermentation, most of the citric acid was consumed (Table 1). An increase in the acetic acid concentration was also detected during the same period, so citric acid could have been converted into acetic acid by the lactic acid bacteria; such a collateral effect usually increases the final acetic acid concentration $[29,62]$ and decreases the wine quality.

\subsection{Volatile Aromatics}

The concentrations of higher alcohols were higher in fermentations involving L. thermotolerans and S. cerevisiae than in those involving S. pombe (Table 2). Several non-Saccharomyces yeast species produced less of the higher alcohols than S. cerevisiae $[7,17,36,47,63-65]$, but great variability among strains has been reported [10]. S. pombe has been reported to produce more of the higher alcohols than S. cerevisiae [30], but selected strains have also been described as low producers [14].

The production of wines with lower levels of higher alcohols has been reported as a way to produce wines with typicity for specific grape varieties or to increase wine complexity [66]. Similarly, fermentation with $S$. pombe alone produced a lower concentration of esters such as isoamyl acetate. Compounds considered negative for winemaking, such as ethyl acetate and diacetyl, were higher in fermentations involving malolactic fermentation. Similar results have been reported previously $[29,67]$. 
Acetaldehyde levels were reduced during trials involving malolactic fermentation (Table 2). Ethyl lactate was higher in fermentations involving $L$. thermotolerans or malolactic fermentation.

Table 2. Final analysis of volatile compounds from fermentations by Saccharomyces cerevisiae 88 alone (SC), sequential fermentation with Saccharomyces cerevisiae 88 and Lachancea thermotolerans CONCERTO ${ }^{\mathrm{TM}}$ (LT‥SC), sequential fermentation with Schizosaccharomyces pombe 4.5 and Lachancea thermotolerans CONCERTO $^{\text {TM }}$ (LT ... SK), Schizosaccharomyces pombe 4.5 alone (SK), and fermentations after malolactic fermentation with Oenococcus oeni 217 (+MLF).

\begin{tabular}{|c|c|c|c|c|c|c|}
\hline Compounds (mg/L) & SC & SC + MLF & LT...SC & LT $\cdots S C+$ MLF & LT...SK & SK \\
\hline Acetaldehyde & $21.56 \pm 1.88_{c}$ & $2.58 \pm 0.27 \mathrm{a}$ & $17.83 \pm 2.56_{\mathrm{cb}}$ & $3.12 \pm 0.58 \mathrm{a}$ & $15.32 \pm 2.02 \mathrm{~b}$ & $16.21 \pm 1.74_{b}$ \\
\hline Ethyl lactate & $2.88 \pm 0.22 \mathrm{a}$ & $22.52 \pm 1.16_{\mathrm{d}}$ & $16.42 \pm 0.89 \mathrm{~b}$ & $29.63 \pm 2.32 \mathrm{e}$ & $19.78 \pm 1.02_{c}$ & $3.38 \pm 0.31 \mathrm{a}$ \\
\hline Ethyl acetate & $19.42 \pm 2.15 \mathrm{a}$ & $32.42 \pm 2.83_{\mathrm{b}}$ & $21.58 \pm 3.01 \mathrm{a}$ & $30.62 \pm 3.88_{b}$ & $19.83 \pm 2.74 \mathrm{a}$ & $18.77 \pm 2.32 \mathrm{a}$ \\
\hline Diacetyl & $2.22 \pm 0.18_{\mathrm{a}}$ & $13.46 \pm 1.08_{\mathrm{b}}$ & $2.41 \pm 0.37 \mathrm{a}$ & $11.64 \pm 2.36_{b}$ & $2.35 \pm 0.41_{\mathrm{a}}$ & $2.16 \pm 0.21 \mathrm{a}$ \\
\hline Isoamyl acetate & $3.73 \pm 0.45_{b}$ & $3.46 \pm 0.41_{\mathrm{b}}$ & $3.87 \pm 0.82_{b}$ & $3.59 \pm 0.91_{b}$ & $2.93 \pm 0.98 \mathrm{ab}$ & $2.12 \pm 0.26 \mathrm{a}$ \\
\hline 1-Propanol & $24.41 \pm 2.75_{c}$ & $24.92 \pm 2.93_{c}$ & $28.51 \pm 3.82_{c}$ & $29.02 \pm 4.13_{c}$ & $18.21 \pm 1.99 \mathrm{~b}$ & $12.56 \pm 1.84 \mathrm{a}$ \\
\hline Isobutanol & $17.02 \pm 2.11_{b}$ & $16.82 \pm 2.31_{b}$ & $24.16 \pm 2.31_{c}$ & $23.98 \pm 2.61_{c}$ & $21.16 \pm 2.92 \mathrm{bc}$ & $7.88 \pm 1.61 \mathrm{a}$ \\
\hline 1-Butanol & $5.44 \pm 0.46_{\mathrm{b}}$ & $2.86 \pm 0.58 \mathrm{a}$ & $7.12 \pm 1.23_{\mathrm{b}}$ & $4.89 \pm 1.56_{\mathrm{ab}}$ & $5.11 \pm 0.82 \mathrm{~b}$ & $3.21 \pm 0.42 \mathrm{a}$ \\
\hline 2-Methyl-butanol & $46.21 \pm 4.53 \mathrm{~d}$ & $53.49 \pm 4.87 \mathrm{~d}$ & $42.17 \pm 5.78_{\mathrm{cd}}$ & $49.21 \pm 6.12 \mathrm{~d}$ & $32.07 \pm 6.82 \mathrm{c}$ & $22.16 \pm 1.93 \mathrm{a}$ \\
\hline 3-Methyl-butanol & $29.23 \pm 2.54_{c}$ & $31.56 \pm 2.77_{c}$ & $27.76 \pm 2.88_{c}$ & $30.11 \pm 3.15_{c}$ & $19.12 \pm 2.63 \mathrm{~b}$ & $14.83 \pm 1.52 \mathrm{a}$ \\
\hline Isobutyl acetate & n.d. & n.d. & n.d. & n.d. & n.d. & n.d. \\
\hline Ethyl butyrate & n.d. & n.d. & n.d. & n.d. & n.d. & n.d. \\
\hline Hexanol & $2.17 \pm 0.18_{b}$ & $1.86 \pm 0.21_{b}$ & $2.21 \pm 0.32 \mathrm{~b}$ & $2.02 \pm 0.38_{b}$ & $1.89 \pm 0.39_{b}$ & $1.21 \pm 0.14 \mathrm{a}$ \\
\hline 2-Phenyl-ethanol & $30.12 \pm 1.88_{\mathrm{b}}$ & $32.42 \pm 2.59 \mathrm{~b}$ & $27.23 \pm 2.64_{b}$ & $28.84 \pm 3.56_{\mathrm{b}}$ & $25.23 \pm 3.06 \mathrm{ab}$ & $22.35 \pm 2.23 \mathrm{a}$ \\
\hline 2-Phenyl ethyl acetate & $6.85 \pm 0.36_{b}$ & $7.13 \pm 0.48_{b}$ & $6.41 \pm 0.51_{b}$ & $6.66 \pm 0.62 \mathrm{~b}$ & $6.02 \pm 0.63_{\mathrm{b}}$ & $5.21 \pm 0.22 \mathrm{a}$ \\
\hline
\end{tabular}

Results are the mean \pm SD of three replicates. Means in the same row with the same letter are not significantly different $(p<0.05)$, n.d. $=$ not detected.

\subsection{Biogenic Amines}

Biogenic amines [68-71] have been proven to be harmful for human health, so they must be taken into account for food safety. A histamine concentration of $2 \mathrm{mg} / \mathrm{L}$ is the highest allowable concentration in some countries [72]. The final levels of histamine in all fermentations were lower than $2 \mathrm{mg} / \mathrm{L}$ (Table 3). Fermentations involving S. pombe showed lower concentrations than those involving a malolactic fermentation (Table 3). Schizosaccharomyces has been reported as effective in reducing the risk of the formation of biogenic amines [20,29,33] or ethyl carbamate precursors [14,31].

Table 3. Final analysis of biogenic amines from fermentations by Saccharomyces cerevisiae 88 alone (SC), sequential fermentation with Saccharomyces cerevisiae 88 and Lachancea thermotolerans CONCERTO ${ }^{\mathrm{TM}}$ (LT ... SC), sequential fermentation with Schizosaccharomyces pombe 4.5 and Lachancea thermotolerans CONCERTO ${ }^{\mathrm{TM}}$ (LT ... SK), Schizosaccharomyces pombe 4.5 alone (SK), and fermentations after malolactic fermentation with Oenococcus oeni 217 (+MLF).

\begin{tabular}{|c|c|c|c|c|c|c|c|}
\hline Compounds & Must & SC & SC + MLF & LT...SC & LT $\cdots S C+M L F$ & LT...SK & SK \\
\hline Histamine $(\mathrm{mg} / \mathrm{L})$ & $0.13 \pm 0.01 \mathrm{a}$ & $0.12 \pm 0.03 \mathrm{a}$ & $0.56 \pm 0.06_{b}$ & $0.16 \pm 0.05 \mathrm{a}$ & $0.51 \pm 0.08_{\mathrm{b}}$ & $0.13 \pm 0.06 \mathrm{a}$ & $0.18 \pm 0.04 \mathrm{a}$ \\
\hline Tiramine (mg/L) & $0.09 \pm 0.01 \mathrm{a}$ & $0.08 \pm 0.02 \mathrm{a}$ & $0.12 \pm 0.05 \mathrm{a}$ & $0.10 \pm 0.06 \mathrm{a}$ & $0.14 \pm 0.09 \mathrm{a}$ & $0.11 \pm 0.06 \mathrm{a}$ & $0.09 \pm 0.02 \mathrm{a}$ \\
\hline Phenylethylamine $(\mathrm{g} / \mathrm{L})$ & n.d. & n.d. & n.d. & n.d. & n.d. & n.d. & n.d. \\
\hline Putrescine $(\mathrm{g} / \mathrm{L})$ & $0.18 \pm 0.02 \mathrm{a}$ & $0.21 \pm 0.03 \mathrm{a}$ & $0.25 \pm 0.09 \mathrm{a}$ & $0.19 \pm 0.06 \mathrm{a}$ & $0.22 \pm 0.08 \mathrm{a}$ & $0.18 \pm 0.07 \mathrm{a}$ & $0.16 \pm 0.03 \mathrm{a}$ \\
\hline Cadaverine $(\mathrm{g} / \mathrm{L})$ & $0.27 \pm 0.02 \mathrm{a}$ & $0.31 \pm 0.03 \mathrm{a}$ & $0.35 \pm 0.07 \mathrm{a}$ & $0.29 \pm 0.07 \mathrm{a}$ & $0.32 \pm 0.09 \mathrm{a}$ & $0.27 \pm 0.06 \mathrm{a}$ & $0.25 \pm 0.03 \mathrm{a}$ \\
\hline
\end{tabular}

Results represent the mean \pm SD for three replicates. Means in the same row with the same letter are not significantly different $(p<0.05)$, n.d. = not detected.

No significant differences were observed for any biogenic amine, except for histamine when a malolactic fermentation occurred (Table 3). However, the histamine levels were always below $2 \mathrm{mg} / \mathrm{L}$. Other authors have reported slight differences related to the ability of yeast strains to remove biogenic amines during fermentation $[14,29,73]$. This phenomenon was not observed in this study, probably due to the low initial level of biogenic amines in the initial must (Table 3). Biogenic amine levels mainly increase during wine ageing and malolactic fermentation [74-77]. 


\subsection{Amino Acids}

Higher final concentrations of most amino acids occurred in S. pombe fermentations (Table 4). Previous studies reported S. pombe as demanding less nitrogen [30] and releasing more nitrogen than S. cerevisiae [14]. S. cerevisiae and L. thermotolerans fermentations produced a higher final concentration of ornithine than $S$. pombe (Table 4). Some authors observed a relationship between threonine, valine, isoleucine and leucine (Table 4) and the higher alcohols 1-propanol, isobutanol, 2-methylbutanol and 3-methylbutanol [45], which explains the differences observed in the final concentrations of higher alcohols after alcoholic fermentation in the presence of these amino acids (Table 4) because they are precursors of higher alcohols (Table 4) [45]. S. pombe fermentations had higher concentrations in the amino acid precursors of higher alcohols (Table 4). S. pombe pure fermentations showed increased histidine, tyrosine and lysine concentrations; those amino acids are biogenic amine precursors [72,74]. This phenomena was not observed for a combined fermentation with $S$. pombe and L. thermotolerans. The transformation of some precursors into biogenic amines occurs during a malolactic fermentation [74-76]; therefore, the wines fermented by $S$. pombe did not have a serious risk of high levels of histamine or tyramine because a long malolactic fermentation was unnecessary [31]. On the other hand, combined fermentations with L. thermotolerans and S. pombe were characterized by lower levels of biogenic amine precursors than $S$. pombe alone, even though malolactic fermentation was also not required (Table 4). Therefore, such biotechnology could be important for wine ageing or ageing over lees because such wines would be more acidic and have a lower content of biogenic amine precursors than wines fermented by $S$. pombe alone. The wines involving a malolactic fermentation showed a reduction in arginine and histidine, and a slight increase in glycine, alanine and ornithine.

Table 4. Final analysis of amino acids from fermentations by Saccharomyces cerevisiae 88 alone (SC), sequential fermentation with Saccharomyces cerevisiae 88 and Lachancea thermotolerans CONCERTO ${ }^{\mathrm{TM}}$ (LT ... SC), sequential fermentation with Schizosaccharomyces pombe 4.5 and Lachancea thermotolerans CONCERTO ${ }^{\text {TM }}$ (LT ... SK), Schizosaccharomyces pombe 4.5 alone (SK), and fermentations after malolactic fermentation with Oenococcus oeni 217 (+MLF).

\begin{tabular}{|c|c|c|c|c|c|c|}
\hline Compounds (mg/L) & SC & SC + MLF & LT ... SC & LT . . SC + MLF & LT ... SK & SK \\
\hline Aspartic acid & $10.08 \pm 0.61 \mathrm{a}$ & $11.56 \pm 0.92 \mathrm{a}$ & $9.42 \pm 1.02 \mathrm{a}$ & $10.64 \pm 1.33 \mathrm{a}$ & $11.62 \pm 1.78 \mathrm{a}$ & $13.76 \pm 0.71_{b}$ \\
\hline Asparagine & $14.23 \pm 1.08 \mathrm{ab}$ & $15.39 \pm 1.32 \mathrm{~b}$ & $12.48 \pm 1.33_{\mathrm{a}}$ & $13.62 \pm 1.64 \mathrm{ab}$ & $16.55 \pm 1.52 \mathrm{~b}$ & $23.42 \pm 1.43_{c}$ \\
\hline Serine & $2.57 \pm 0.41_{\mathrm{a}}$ & $3.71 \pm 0.52 \mathrm{~b}$ & $2.47 \pm 0.50 \mathrm{a}$ & $3.62 \pm 0.58_{\mathrm{b}}$ & $3.88 \pm 0.64_{\mathrm{b}}$ & $5.11 \pm 0.72 \mathrm{c}$ \\
\hline Histidine & $58.42 \pm 2.79 \mathrm{~b}$ & $50.63 \pm 3.08 \mathrm{a}$ & $61.31 \pm 3.92_{\mathrm{b}}$ & $52.53 \pm 4.21 \mathrm{a}$ & $62.93 \pm 4.32 \mathrm{~b}$ & $79.21 \pm 3.22_{c}$ \\
\hline Glycine & $25.22 \pm 1.35 \mathrm{~b}$ & $29.86 \pm 1.61_{c}$ & $16.42 \pm 2.16_{\mathrm{a}}$ & $19.76 \pm 2.52 \mathrm{a}$ & $16.96 \pm 2.22 \mathrm{a}$ & $26.14 \pm 1.44_{b}$ \\
\hline Arginine & $56.42 \pm 2.79 \mathrm{~b}$ & $45.63 \pm 3.08 \mathrm{a}$ & $57.31 \pm 3.92 \mathrm{~b}$ & $48.53 \pm 3.21_{\mathrm{a}}$ & $55.26 \pm 3.43_{\mathrm{b}}$ & $70.36 \pm 4.79 \mathrm{c}$ \\
\hline Threonine & $19.36 \pm 1.89 \mathrm{a}$ & $21.26 \pm 2.14 \mathrm{a}$ & $18.24 \pm 2.11_{\mathrm{a}}$ & $20.13 \pm 2.45 \mathrm{a}$ & $28.42 \pm 2.93 \mathrm{~b}$ & $46.58 \pm 4.01_{\mathrm{c}}$ \\
\hline Alanine & $26.31 \pm 2.41 \mathrm{a}$ & $35.52 \pm 2.96 \mathrm{a}$ & $25.77 \pm 2.88 a$ & $33.66 \pm 3.17 \mathrm{a}$ & $26.52 \pm 2.72 \mathrm{a}$ & $24.14 \pm 1.99 \mathrm{a}$ \\
\hline Tyrosine & $3.75 \pm 0.21 \mathrm{a}$ & $3.89 \pm 0.29 \mathrm{a}$ & $3.67 \pm 0.36 \mathrm{a}$ & $3.93 \pm 0.45 \mathrm{a}$ & $4.12 \pm 0.98 \mathrm{a}$ & $7.38 \pm 0.74_{\mathrm{b}}$ \\
\hline Valine & $1.36 \pm 0.14_{\mathrm{b}}$ & $1.35 \pm 0.58_{\mathrm{b}}$ & $0.32 \pm 0.28 \mathrm{a}$ & $0.33 \pm 0.45 \mathrm{a}$ & $1.32 \pm 0.65_{\mathrm{b}}^{\mathrm{a}}$ & $5.89 \pm 0.44 \mathrm{~d}$ \\
\hline Tryptophan & $0.24 \pm 0.04 \mathrm{a}$ & $0.55 \pm 0.16_{\mathrm{b}}$ & $0.28 \pm 0.07 \mathrm{a}$ & $0.61 \pm 0.21_{\mathrm{b}}$ & $1.05 \pm 0.76_{\mathrm{bc}}$ & $2.11 \pm 0.31_{c}$ \\
\hline Phenylalanine & $2.96 \pm 0.27 \mathrm{a}$ & $3.17 \pm 0.38 \mathrm{a}$ & $2.77 \pm 0.41_{\mathrm{a}}$ & $3.02 \pm 0.55 \mathrm{a}$ & $4.67 \pm 0.72 \mathrm{~b}$ & $6.82 \pm 0.55_{c}$ \\
\hline Isoleucine & $3.16 \pm 0.23_{\mathrm{b}}$ & $2.76 \pm 0.31 \mathrm{a}$ & $5.22 \pm 0.41_{\mathrm{d}}$ & $4.28 \pm 0.67_{\mathrm{c}}$ & $8.87 \pm 0.87 \mathrm{e}$ & $14.16 \pm 0.82_{\mathrm{f}}$ \\
\hline Leucine & $3.84 \pm 0.42 \mathrm{~b}$ & $2.53 \pm 0.51_{\mathrm{a}}$ & $4.92 \pm 0.62 \mathrm{~d}$ & $4.11 \pm 0.87 \mathrm{bd}$ & $9.96 \pm 1.12 \mathrm{e}$ & $18.43 \pm 1.06_{\mathrm{f}}$ \\
\hline Ornithine & $38.21 \pm 2.17_{c}$ & $44.37 \pm 2.88_{\mathrm{d}}$ & $36.32 \pm 3.21_{c}$ & $42.16 \pm 3.94 \mathrm{~cd}$ & $28.33 \pm 2.51_{b}$ & $21.15 \pm 1.82 \mathrm{a}$ \\
\hline Lysine & $8.52 \pm 0.77 \mathrm{a}$ & $9.68 \pm 0.86 \mathrm{a}$ & $8.96 \pm 1.35 \mathrm{a}$ & $10.58 \pm 1.33 \mathrm{a}$ & $8.78 \pm 1.72 \mathrm{a}$ & $15.16 \pm 1.02 \mathrm{~b}$ \\
\hline Methionine & $1.11 \pm 0.18 \mathrm{a}$ & $1.82 \pm 0.31_{\mathrm{b}}$ & $1.08 \pm 0.24 \mathrm{a}$ & $1.68 \pm 0.44 \mathrm{ab}$ & $1.46 \pm 0.31 \mathrm{ab}$ & $2.45 \pm 0.29_{c}$ \\
\hline
\end{tabular}

Results represent the mean \pm SD for three replicates. Means in the same row with the same letter are not significantly different $(p<0.05)$.

\subsection{Colour Measurements}

Table 5 shows the results of colour assessments for the different treatments. Fermentations involving $S$. pombe alone showed higher colour intensity values. Similar results have been reported previously [29]. Significant differences were observed in the hue parameters when malolactic fermentation took place. 
Table 5. Colour measurements in the wines produced by the different fermentation assays: Saccharomyces cerevisiae 88 alone (SC), sequential fermentation with Saccharomyces cerevisiae 88 and Lachancea thermotolerans CONCERTO ${ }^{\mathrm{TM}}$ (LT...SC), sequential fermentation with Schizosaccharomyces pombe 4.5 and Lachancea thermotolerans CONCERTO ${ }^{\mathrm{TM}}$ (LT ... SK), Schizosaccharomyces pombe 4.5 alone (SK), and fermentations after malolactic fermentation with Oenococcus oeni 217 (+MLF).

\begin{tabular}{|c|c|c|c|c|c|c|}
\hline Compounds & SC & $\mathrm{SC}+\mathrm{MLF}$ & LT ... SC & LT ... SC + MLF & LT ... SK & SK \\
\hline $420 \mathrm{~nm}$ & $6 \pm 1_{a}$ & $6 \pm 1_{a}$ & $7 \pm 1_{\mathrm{a}}$ & $7 \pm 1_{a}$ & $7 \pm 1_{\mathrm{a}}$ & $08 \pm 1_{\mathrm{a}}$ \\
\hline $520 \mathrm{~nm}$ & $8 \pm 1_{b}$ & $6 \pm 1 \mathrm{a}$ & $9 \pm 1_{b}$ & $7 \pm 1 \mathrm{a}$ & $9 \pm 1_{b c}$ & $10 \pm 1_{\mathrm{c}}$ \\
\hline $620 \mathrm{~nm}$ & $2 \pm 1_{\mathrm{a}}$ & $2 \pm 1_{a}$ & $1 \pm 1_{\mathrm{a}}$ & $1 \pm 1_{\mathrm{a}}$ & $02 \pm 1_{\mathrm{a}}$ & $2 \pm 1_{\mathrm{a}}$ \\
\hline $\mathrm{Cia}<$ & $16 \pm 1 \mathrm{ab}$ & $14 \pm 1_{\mathrm{a}}$ & $17 \pm 1_{\mathrm{ab}}$ & $15 \pm 1_{\mathrm{a}}$ & $18 \pm 1_{\mathrm{bc}}$ & $20 \pm 1_{c}$ \\
\hline Hue & $0.75 \pm 0.02 \mathrm{a}$ & $1.00 \pm 0.02 \mathrm{~b}$ & $0.77 \pm 2 \mathrm{a}$ & $1.00 \pm 0.02_{b}$ & $0.77 \pm 0.02 \mathrm{a}$ & $0.80 \pm 0.02 \mathrm{a}$ \\
\hline
\end{tabular}

Results are the mean \pm SD of three replicates. Means in the same row with the same letter are not significantly different $(p<0.05)$.

\subsection{Ethanol Index}

Some authors have described some non-Saccharomyces and specifically Schizosaccharomyces yeasts as higher producers of polysaccharides $[4,22,78]$. To estimate the content of polysaccharides, the ethanol index was used in this study (Figure 6). Fermentations involving S. pombe showed higher ethanol index values. These results match the information gave by previous authors [4,22].

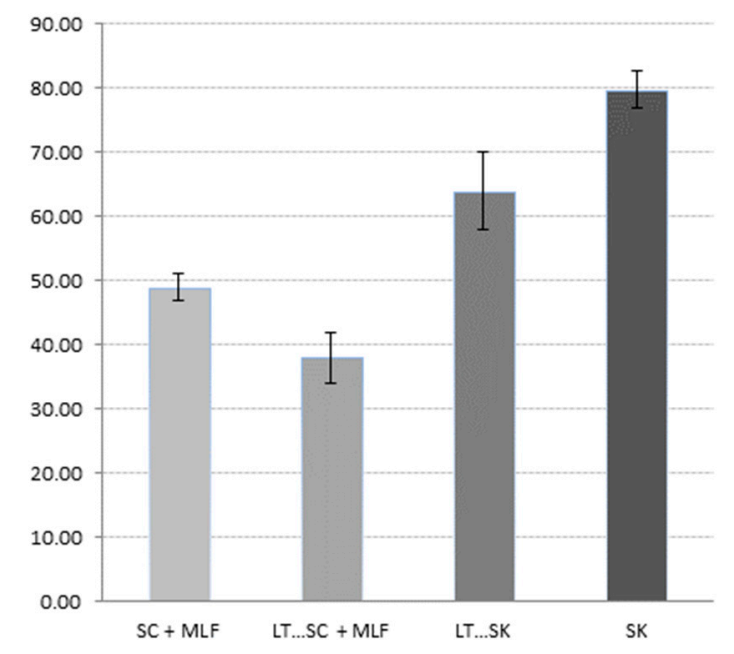

Figure 6. Results of the ethanol index analysis of bottled wines from different fermentation processes of Saccharomyces cerevisiae 88 alone (SC), sequential fermentation with Saccharomyces cerevisiae 88 and Lachancea thermotolerans CONCERTO ${ }^{\mathrm{TM}}$ (LT ... SC), sequential fermentation with Schizosaccharomyces pombe 4.5 and Lachancea thermotolerans CONCERTO ${ }^{\mathrm{TM}}$ (LT ... SK), Schizosaccharomyces pombe 4.5 alone (SK), and fermentations after malolactic fermentation with Oenococcus oeni 217 (+ MLF).

\subsection{Sensory Evaluation}

Figure 7 shows the spider web diagram of the average scores of the taste and olfactory attributes that were assessed. Large differences in the perception of acidity were recorded; this result agrees with the acidity parameters explained above (Table 1). Alcoholic fermentation followed by malolactic fermentation produced a slightly stronger sensation of oxidation and acetic acidity. Nevertheless, no serious faults were reported for any of the wines. None of the wines produced by fermentation with S. pombe showed any perceptible organoleptic problems; indeed, the combination between S. pombe and $L$. Thermotolerans received the best scores from all tasters. Although all fermentations involving S. pombe achieved the main goals related to microbiological malic acid stabilization. The preferred fermentation strategy was a combined use of $S$. pombe and L. Thermotolerans, probably because the fermented must was less standardized, fruitier and possessed a higher acidity. Differences in the colour 
intensity could be explained by the pyruvic acid production noted above or the different absorption of coloured compounds by the yeast species (Table 5).

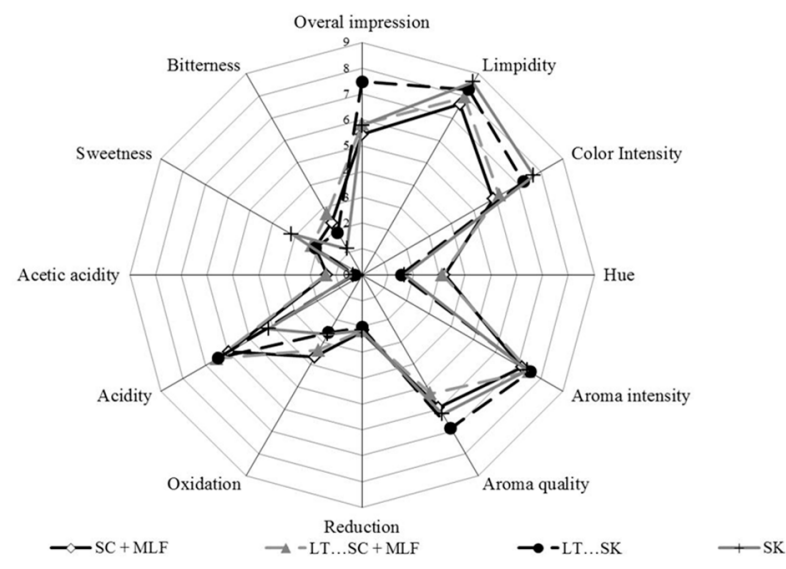

Figure 7. Results of the sensory analysis of bottled wines from different fermentation processes of Saccharomyces cerevisiae 88 alone (SC), sequential fermentation with Saccharomyces cerevisiae 88 and Lachancea thermotolerans CONCERTO ${ }^{\mathrm{TM}}$ (LT ... SC), sequential fermentation with Schizosaccharomyces pombe 4.5 and Lachancea thermotolerans CONCERTO ${ }^{\mathrm{TM}}$ (LT ... SK), Schizosaccharomyces pombe 4.5 alone (SK), and fermentations after malolactic fermentation with Oenococcus oeni 217 (+ MLF). The intensity of the 12 attributes was scaled from 0 (no character) to 10 (very strong character).

\section{Materials and Methods}

\subsection{Microorganisms}

The following yeast strains were used for the experimental fermentations: Kluyveromyces thermotolerans Concerto ${ }^{\mathrm{TM}}$ (Hansen, Hørsholm, Denmark; www.chr-hansen.com) that belongs to the yeast species Lachancea thermotolerans, Saccharomyces cerevisiae 88 (Spanish Type Culture Collection, Valencia, Spain) and Schizosaccharomyces pombe 4.5 (Chemistry and Food Technology department, Polytechnic University of Madrid, Madrid, Spain [42]. The strain of lactic acid bacteria used was Oenococcus oeni 217 (Spanish Type Culture Collection).

\subsection{Vinification}

All fermentations used a must of Vitis vinifera L. cultivar Tempranillo grapes grown at the El Socorro Experimental vineyard (Madrid, Spain). The must was pasteurized at $105^{\circ} \mathrm{C}$ for $5 \mathrm{~min}$. A microvinification method similar to that described in the scientific literature was used [45]. Pasteurized must $(4 \mathrm{~L})$ was placed in a 5 L glass tank, allowing adequate space for the release of carbon dioxide during fermentation. No sulphur dioxide was added. The sugar concentration was $253 \mathrm{~g} / \mathrm{L}, \mathrm{pH}=3.88$, primary amino nitrogen (PAN) $144 \mathrm{~g} / \mathrm{L}$, malic acid $1.33 \mathrm{~g} / \mathrm{L}$, citric acid $0.2 \mathrm{~g} / \mathrm{L}$, lactic and acetic acid bellow $0.1 \mathrm{~g} / \mathrm{L}$. To provide nutrition $40 \mathrm{~g} / \mathrm{hL}$ of Actimax NATURA (Agrovín S.A., Ciudad Real, Spain) were added. Four treatments were used (all in triplicate): (i) inoculation of the must with S. cerevisiae $88\left(10^{7} \mathrm{CFU} / \mathrm{mL}\right)$ alone (SC); (ii) inoculation of the must with L. thermotolerans Concerto ${ }^{\mathrm{TM}}\left(10^{7} \mathrm{CFU} / \mathrm{mL}\right)$ followed by S. cerevisiae $88\left(10^{7} \mathrm{CFU} / \mathrm{mL}\right) 96 \mathrm{~h}$ later (LT ... SC); (iii) inoculation of the must with L. thermotolerans Concerto ${ }^{\mathrm{TM}}\left(10^{7} \mathrm{CFU} / \mathrm{mL}\right)$ followed by S. pombe $4.5\left(10^{7} \mathrm{CFU} / \mathrm{mL}\right) 96 \mathrm{~h}$ later (KT ... SK); and (iv) inoculation of the must with S. pombe $4.5\left(10^{7} \mathrm{CFU} / \mathrm{mL}\right)$ alone (SK). Yeasts were inoculated using $400 \mathrm{~mL}$ of sterilized must containing $10^{8} \mathrm{CFU} / \mathrm{mL}$ (determined using a Thomas chamber). To reach this population, $100 \mu \mathrm{L}$ of each yeast suspension were cultivated in $10 \mathrm{~mL}$ of YEPD at $25^{\circ} \mathrm{C}$ for $24 \mathrm{~h}$. This procedure was repeated three times successively before the final inoculation of $4 \mathrm{~mL}$ in the inocula. All inoculations were performed in 500-mL flasks sealed with a Müller valve filled with $98 \% \mathrm{H}_{2} \mathrm{SO}_{4}$ (Panreac, Barcelona, Spain), 
which allowed the release of $\mathrm{CO}_{2}$ while avoiding microbial contamination [46]. The temperature was maintained at $25^{\circ} \mathrm{C}$ for $72 \mathrm{~h}$ before inoculation. The inocula were developed under anaerobic conditions. All fermentations were performed in triplicate. All fermentation processes were carried out at $25{ }^{\circ} \mathrm{C}$. When the sugar content was below $2 \mathrm{~g} / \mathrm{L}$, the wines were racked and stabilized for 7 days at $4{ }^{\circ} \mathrm{C}$, after which the final product was bottled. Then, a concentration of $50 \mathrm{mg} / \mathrm{L}$ of sulphur dioxide in potassium metabisulphite form was added. Sealed bottles were placed horizontally in a climate chamber at $4{ }^{\circ} \mathrm{C}$ until the sensory evaluation took place. The wines fermented with Saccharomyces cerevisiae alone (SC) were stabilized and racked following the same procedure when the malolactic fermentation by Oenococcus oeni $217\left(10^{7} \mathrm{CFU} / \mathrm{mL}\right)$ was finished in $2.8 \mathrm{~L}$ vessels at $18^{\circ} \mathrm{C}$. These wines remained under the same storage conditions described above, for one month before the tasting sessions took place.

\subsection{Measurements of Biochemical Compounds And $p H$}

Determination of glucose + fructose, malic acid, L-lactic acid, acetic acid, pyruvic acid, urea, ethanol index [79] and glycerol concentrations as well as colour intensity (Table 1) were conducted using a Y15 Autoanalyser and a Y350 Semiautomatic Analyzer (Biosystems, Barcelona, Spain). The kits used to perform the analyses were obtained from Biosystems (www.biosystems.es). The quantification metrology was performed according to the manufacturer's indications from the standards contained in the commercial kits (www.biosystems.es). The alcohol content was determined by using the GAB Microebu ebuillometry method (http://shop.gabsystem.com). The $\mathrm{pH}$ was measured with a Crison pH Meter Basic 20 (Crison, Barcelona, Spain).

\subsection{Microvinification Growth Kinetics}

Aliquots were periodically taken aseptically during fermentation and further ten-fold serial dilutions were made. The yeast growth kinetics were monitored by plating $100 \mu \mathrm{L}$ of the appropriate dilution on lysine media (non-Saccharomyces counts; [80]), YEPD media (total yeast counts; [81,82]) and YEPDActBzCl media (Schizosaccharomyces counts; [43]) with actidione and benzoic acid as the main inhibitors. In LT ... SC fermentations, the population of Lachancea thermotolerans was estimated by the difference between the YEPD and the Lysine media counts. In LT ... SK fermentations, the population of Lachancea thermotolerans was estimated by the difference between the YEPD and YEPDActBzCl media counts. Colonies were counted after growth at $30{ }^{\circ} \mathrm{C}$ for $48-72 \mathrm{~h}$. Lactic acid bacteria were monitored in MRS agar (Oxoid, Basingstoke, UK).

\subsection{Quantification of Volatile Compounds}

Volatile compounds (Table 2) were quantified by headspace gas chromatography-mass spectrometry (HS-GC-MS). Analyses were carried out using a Clarus 500 gas chromatograph (Perkin-Elmer, Waltham, MA, USA) equipped with a flame ionization detector coupled to a single quadrupole Clarus $560 \mathrm{~S}$ mass spectrometer, all coupled to an Turbomatrix 110 Trap automatic headspace sampler (Perkin-Elmer). The headspace sampler conditions were: thermostat temperature: $80{ }^{\circ} \mathrm{C}$, time of thermostating: $45 \mathrm{~min}$, type of trap: Tenax TA, cycles of purge and trap: 4 , temperature of trap capture: $45^{\circ} \mathrm{C}$, desorption temperature of the trap: $290^{\circ} \mathrm{C}$, time of dry trap purge: $10 \mathrm{~min}$, desorption time of trap: $2 \mathrm{~min}$, trap cleaning time: $5 \mathrm{~min}$, needle temperature: $110^{\circ} \mathrm{C}$, temperature of HS-GC transfer line: $150{ }^{\circ} \mathrm{C}$, vial pressure: 30 psi and constant pressure column: 28 psi. A FFAP capillary column $(60 \mathrm{~m} \times 0.25 \mathrm{~mm}$ DI $\times 0.25 \mu \mathrm{m}$ film thickness) was used. Helium (Air Liquide, Paris, France) was used as the carrier gas. A gradient analysis was run using the following temperature program: $40{ }^{\circ} \mathrm{C}(3 \mathrm{~min}) ; 40-80{ }^{\circ} \mathrm{C}\left(2{ }^{\circ} \mathrm{C} / \mathrm{min}\right) ; 80-180{ }^{\circ} \mathrm{C}\left(3{ }^{\circ} \mathrm{C} / \mathrm{min}\right)$; and $210{ }^{\circ} \mathrm{C}$ (5 min). Identification of individual compounds was based on a comparison of the mass spectra of the individual chromatographic peaks with those valid for the standards and available from the National Institute of Standards and Technology (Gaithersburg, MD, USA) software library. We also compared the retention times for individual peaks from the wine samples with those of the known 
volatile components to use as standard patterns. We used gas chromatography quality compounds as the sets of the volatile standards for this purpose (Fluka, Sigma-Aldrich Corp., Buchs SG, Standort, Switzerland). The apparatus was calibrated with a 4- meth-yl-2-pentanol internal standard at $50 \mathrm{mg} / \mathrm{L}$. An individual calibration for each volatile compound was accomplished using an external standard at six concentrations ranging from 1 to $500 \mathrm{mg} / \mathrm{L}$. The $\mathrm{R} 2$ values were greater than 0.999 for all compounds tested. The detection limit of the method was $0.1 \mathrm{mg} / \mathrm{L}$.

\subsection{Quantification of Biogenic Amines}

Biogenic amines (Table 3) were analysed using a series X-LCTM UHPLC chromatograph (Jasco, Tokyo, Japan), equipped with a 3120-FP fluorescence detector. Gradients of solvent A (methanol/acetonitrile, 50:50, $v / v$ ) and B (sodium acetate/tetrahydrofuran, 99:1, $v / v$ ) were used in a C18 (HALO, Wilmington, DE, USA) column $(100 \mathrm{~mm} \times 2.1 \mathrm{~mm}$; particle size $2.7 \mu \mathrm{m})$ as follows: $60 \% \mathrm{~B}(0.25 \mathrm{~mL} / \mathrm{min})$ from 0 to $5 \mathrm{~min}, 60 \%-50 \%$ B linear $(0.25 \mathrm{~mL} / \mathrm{min})$ from 5 to $8 \mathrm{~min}, 50 \%$ B from 8 to $9 \mathrm{~min}, 50 \%-20 \%$ B linear $(0.2 \mathrm{~mL} / \mathrm{min})$ from 9 to $12 \mathrm{~min}, 20 \% \mathrm{~B}(0.2 \mathrm{~mL} / \mathrm{min})$ from 12 to $13 \mathrm{~min}$, $20 \%-60 \%$ B linear $(0.2 \mathrm{~mL} / \mathrm{min})$ from 13 to $14.5 \mathrm{~min}$, and re-equilibration of the column from 14.5 to $17 \mathrm{~min}$. Detection was performed by scanning in the $340-420 \mathrm{~nm}$ range. Quantification was performed by comparison against appropriate external standards. The different amines were identified by their retention times.

\subsection{Analytical Determination of Amino Acids}

Selected amino acids (Table 4) were analysed using a Jasco series X-LCTM UHPLC chromatograph, equipped with a 3120-FP fluorescence detector. Gradients of solvent A (methanol/acetonitrile, 50:50, $v / v$ ) and B (sodium acetate / tetrahydrofuran, 99:1, $v / v$ ) were used in a C18 (HALO) column $(100 \mathrm{~mm} \times 2.1 \mathrm{~mm}$; particle size $2.7 \mu \mathrm{m})$ as follows: $90 \% \mathrm{~B}(0.25 \mathrm{~mL} / \mathrm{min})$ from 0 to $6 \mathrm{~min}, 90 \%-78 \%$ B linear $(0.2 \mathrm{~mL} / \mathrm{min})$ from 6 to $7.5 \mathrm{~min}, 78 \%$ B from 7.5 to $8 \mathrm{~min}, 78 \%-74 \%$ B linear $(0.2 \mathrm{~mL} / \mathrm{min})$ from 8 to $8.5 \mathrm{~min}, 74 \% \mathrm{~B}(0.2 \mathrm{~mL} / \mathrm{min})$ from 8.5 to $11 \mathrm{~min}, 74 \%-50 \%$ B linear $(0.2 \mathrm{~mL} / \mathrm{min})$ from 11 to $15 \mathrm{~min}, 50 \% \mathrm{~B}(0.2 \mathrm{~mL} / \mathrm{min})$ from 15 to $17 \mathrm{~min}, 50 \%-20 \%$ B linear $(0.2 \mathrm{~mL} / \mathrm{min})$ from 17 to $21 \mathrm{~min}$, $20 \%-90 \%$ B linear $(0.2 \mathrm{~mL} / \mathrm{min})$ from 21 to $25 \mathrm{~min}$, and the column was re-equilibrated from 25 to $26 \mathrm{~min}$. Detection was performed by scanning in the $340-455 \mathrm{~nm}$ range. Quantification was performed by comparison against appropriate external standards. The different amino acids were identified by their retention times.

\subsection{Sensory Analysis}

The final wines were assessed in a blind test by a panel of 15 experienced wine tasters, all of whom were staff members of the Chemistry and Food Technology Department (Madrid, Spain) and the Estación Enológica de Haro (Haro, Spain). Following the generation of a consistent terminology by consensus, three visual descriptors, four aromas and four taste attributes were chosen to describe the wines. Descriptors such as acidity, acetic acid or aroma were chosen in order to contrast the chemical results obtained in the study. The panellists used a $10 \mathrm{~cm}$ unstructured scale, from 0 (no defect) to 10 (very strong perceptible defect) to rate the intensity of the 12 attributes.

\subsection{Statistical Analyses}

All statistical analyses were performed using PC Statgraphics v.5 software (Graphics Software Systems, Rockville, MD, USA). The significance was set to $p<0.05$ for the ANOVA matrix F value. A multiple range test was used to compare the means.

\section{Conclusions}

A combination of selected Schizosaccharomyces pombe and Lachancea thermotolerans yeast strains is an alternative to the traditional malolactic fermentation that positively affects the quality of wine 
produced from musts with low acidity. The results from the fermentation trails showed positive differences in several previous studied parameters such as acetic acid, biogenic amines, glycerol or colour. Fermentations involving S. pombe showed volatile profiles with lower concentrations in higher alcohols while fermentations involving malolactic fermentation showed higher levels in ethyl acetate and diacetyl. Fermentations involving S. pombe resulted in higher levels in final amino acids. Combined fermentations between S. pombe and L. thermotolerans reported higher levels of ethanol index that are related to higher polysaccharides releases. Mixed fermentation involving S. pombe and L. thermotolerans achieved the highest score in overall impression.

Acknowledgments: The authors are grateful to the accredited Estación Enológica de Haro laboratory, where the biogenic amines, amino acids and volatile aroma analysis were performed, especially to Montserrat Iñiguez and Elena Melendez.

Author Contributions: S.B., F.C and A.B conceived and designed the experiments; A.B. performed the experiment; A.B. and F.C. analysed the data; F.C. contributed reagents/materials/analysis tools; A.B. wrote the paper; F.C and S.B. revised the manuscript.

Conflicts of Interest: The authors declare no conflict of interest.

\section{References}

1. Jolly, N.P.; Varela, C.; Pretorius, I.S. Not Your Ordinary Yeast: Non-Saccharomyces Yeasts in Wine Production Uncovered. FEMS Yeast Res. 2014, 14, 215-237. [CrossRef] [PubMed]

2. Padilla, B.; Gil, J.V.; Manzanares, P. Past and Future of Non-Saccharomyces Yeasts: From Spoilage Microorganisms to Biotechnological Tools for Improving Wine Aroma Complexity. Front. Microbiol. 2016, 7, 411. [CrossRef] [PubMed]

3. Rojas, V.; Gil, J.V.; Piñaga, F.; Manzanares, P. Studies on Acetate Ester Production by Non-Saccharomyces Wine Yeasts. Int. J. Food Microbiol. 2001, 70, 283-289. [CrossRef]

4. Domizio, P.; Liu, Y.; Bisson, L.F.; Barile, D. Use of Non-Saccharomyces Wine Yeasts as Novel Sources of Mannoproteins in Wine. Food Microbiol. 2014, 43, 5-15. [CrossRef] [PubMed]

5. Sun, S.Y.; Gong, H.S.; Jiang, X.M.; Zhao, Y.P. Selected Non-Saccharomyces Wine Yeasts in Controlled Multistarter Fermentations with Saccharomyces cerevisiae on Alcoholic Fermentation Behaviour and Wine Aroma of Cherry Wines. Food Microbiol. 2014, 44, 15-23. [CrossRef] [PubMed]

6. Varela, C. The Impact of Non-Saccharomyces Yeasts in the Production of Alcoholic Beverages. Appl. Microbiol. Biotechnol. 2016, 100, 9861-9874. [CrossRef] [PubMed]

7. Belda, I.; Navascués, E.; Marquina, D.; Santos, A.; Calderon, F.; Benito, S. Dynamic Analysis of Physiological Properties of Torulaspora delbrueckii in Wine Fermentations and its Incidence on Wine Quality. Appl. Microbiol. Biotechnol. 2015, 99, 1911-1922. [CrossRef] [PubMed]

8. Lu, Y.; Chua, J.; Huang, D.; Lee, P.; Liu, S. Biotransformation of Chemical Constituents of Durian Wine with Simultaneous Alcoholic Fermentation by Torulaspora delbrueckii. Appl. Microbiol. Biotechnol. 2016, 100, 8877-8888. [CrossRef] [PubMed]

9. Herraiz, T.; Reglero, G.; Herraiz, M.; Martin-Alvarez, P.J.; Cabezudo, M.D. The Influence of the Yeast and Type of Culture on the Volatile Composition of Wines Fermented without Sulfur Dioxide. Am. J. Enol. Vitic. 1990, 41, 313-318.

10. Zironi, R.; Romano, P.; Suzzi, G.; Battistutta, F.; Comi, G. Volatile Metabolites Produced in Wine by Mixed and Sequential Cultures of Hanseniaspora guilliermondii or Kloeckera apiculata and Saccharomyces cerevisiae. Biotechnol. Lett. 1993, 15, 235-238. [CrossRef]

11. Viana, F.; Belloch, C.; Vallés, S.; Manzanares, P. Monitoring a Mixed Starter of Hanseniaspora vineae -Saccharomyces cerevisiae in Natural must: Impact on 2-Phenylethyl Acetate Production. Int. J. Food Microbiol. 2011, 151, 235-240. [CrossRef] [PubMed]

12. Di Maio, S.; Genna, G.; Gandolfo, V.; Amore, G.; Ciaccio, M.; Oliva, D. Presence of Candida zemplinina in Sicilian Musts and Selection of a Strain for Wine Mixed Fermentations. S. Afr. J. Enol. Vitic. 2012, 33, 80-87.

13. Belda, I.; Conchillo, L.B.; Ruiz, J.; Navascués, E.; Marquina, D.; Santos, A. Selection and use of Pectinolytic Yeasts for Improving Clarification and Phenolic Extraction in Winemaking. Int. J. Food Microbiol. 2016, 223, 1-8. [CrossRef] [PubMed] 
14. Benito, Á.; Jeffares, D.; Palomero, F.; Calderón, F.; Bai, F.; Bähler, J.; Benito, S. Selected Schizosaccharomyces pombe Strains have Characteristics that are Beneficial for Winemaking. PloS ONE 2016, 11, e0151102. [CrossRef] [PubMed]

15. Cañas, P.M.I.; García-Romero, E.; Manso, J.M.H.; Fernández-González, M. Influence of Sequential Inoculation of Wickerhamomyces anomalus and Saccharomyces cerevisiae in the Quality of Red Wines. European Food Res. Technol. 2014, 239, 279-286. [CrossRef]

16. Balikci, E.K.; Tanguler, H.; Jolly, N.P.; Erten, H. Influence of Lachancea thermotolerans on Cv. Emir Wine Fermentation. Yeast 2016, 33, 313-321. [CrossRef] [PubMed]

17. Benito, A.; Calderón, F.; Palomero, F.; Benito, S. Quality and Composition of Airen Wines Fermented by Sequential Inoculation of Lachancea thermotolerans and Saccharomyces cerevisiae. Food Technol. Biotechnol. 2016, 54, 250-255. [CrossRef] [PubMed]

18. Rodriguez, S.B.; Thornton, R.J. Factors Influencing the Utilisation of L-Malate by Yeasts. FEMS Microbiol. Lett. 1990, 72, 17-22.

19. Thornton, R.; Rodriguez, S. Deacidification of Red and White Wines by a Mutant of Schizosaccharomyces malidevorans under Commercial Winemaking Conditions. Food Microbiol. 1996, 13, 475-482. [CrossRef]

20. Benito, S.; Palomero, P.; Calderón, F.; Palmero, D.; Suárez-Lepe, J.A. Schizosaccharomyces. In Encyclopedia of Food Microbiology, 2nd ed.; Batt CA, T.M., Ed.; Elsevier: Amsterdam, The Netherlands, 2014; pp. 365-370.

21. Palomero, F.; Morata, A.; Benito, S.; Calderón, F.; Suárez-Lepe, J. New Genera of Yeasts for Over-Lees Aging of Red Wine. Food Chem. 2009, 112, 432-441. [CrossRef]

22. Romani, C.; Domizio, P.; Lencioni, L.; Gobbi, M.; Comitini, F.; Ciani, M.; Mannazzu, I. Polysaccharides and Glycerol Production by Non-Saccharomyces Wine Yeasts in Mixed Fermentation. Quad. Vitic. Enol. Univ. Torino. 2010, 31, 185-189.

23. Peinado, R.A.; Mauricio, J.C.; Medina, M.; Moreno, J.J. Effect of Schizosaccharomyces pombe on Aromatic Compounds in Dry Sherry Wines Containing High Levels of Gluconic Acid. J. Agric. Food Chem. 2004, 52, 4529-4534. [CrossRef] [PubMed]

24. Peinado, R.A.; Moreno, J.J.; Maestre, O.; Ortega, J.M.; Medina, M.; Mauricio, J.C. Gluconic Acid Consumption in Wines by Schizosaccharomyces pombe and its Effect on the Concentrations of Major Volatile Compounds and Polyols. J. Agric. Food Chem. 2004, 52, 493-497. [CrossRef] [PubMed]

25. Peinado, R.A.; Moreno, J.J.; Medina, M.; Mauricio, J.C. Potential Application of a Glucose-Transport-Deficient Mutant of Schizosaccharomyces pombe for Removing Gluconic Acid from Grape Must. J. Agric. Food Chem. 2005, 53, 1017-1021. [CrossRef] [PubMed]

26. Peinado, R.A.; Moreno, J.J.; Maestre, O.; Mauricio, J.C. Removing Gluconic Acid by using Different Treatments with a Schizosaccharomyces pombe Mutant: Effect on Fermentation Byproducts. Food Chem. 2007, 104, 457-465. [CrossRef]

27. Peinado, R.A.; Maestre, O.; Mauricio, J.C.; Moreno, J.J. Use of a Schizosaccharomyces pombe Mutant to Reduce the Content in Gluconic Acid of must obtained from Rotten Grapes. J. Agric. Food Chem. 2009, 57, 2368-2377. [CrossRef] [PubMed]

28. Benito, S.; Palomero, F.; Gálvez, L.; Morata, A.; Calderón, F.; Palmero, D.; Suárez-Lepe, J.A. Quality and Composition of Red Wine Fermented with Schizosaccharomyces pombe as Sole Fermentative Yeast, and in Mixed and Sequential Fermentations with Saccharomyces Cerevisiae. Food Technol. Biotechnol. 2014, 52, 376-382.

29. Mylona, A.; Del Fresno, J.; Palomero, F.; Loira, I.; Bañuelos, M.; Morata, A.; Calderón, F.; Benito, S.; Suárez-Lepe, J. Use of Schizosaccharomyces Strains for Wine fermentation-Effect on the Wine Composition and Food Safety. Int. J. Food Microbiol. 2016, 232, 63-72. [CrossRef] [PubMed]

30. Benito, S.; Palomero, F.; Morata, A.; Calderón, F.; Suárez-Lepe, J.A. New Applications for Schizosaccharomyces pombe in the Alcoholic Fermentation of Red Wines. Int. J. Food Sci. Tech. 2012, 47, 2101-2108. [CrossRef]

31. Benito, S. The use of Schizosaccharomyces Yeast in Order to Reduce the Content of Biogenic Amines and Ethyl Carbamate in Wines. J. Food Process Technol. 2015, 6, 9-10.

32. Lubbers, M.W.; Rodriguez, S.B.; Honey, N.K.; Thornton, R.J. Purification and Characterization of Urease from Schizosaccharomyces pombe. Can. J. Microbiol. 1996, 42, 132-140. [CrossRef] [PubMed]

33. Benito, Á.; Calderón, F.; Palomero, F.; Benito, S. Combine use of Selected Schizosaccharomyces pombe and Lachancea thermotolerans Yeast Strains as an Alternative to the Traditional Malolactic Fermentation in Red Wine Production. Molecules 2015, 20, 9510-9523. [CrossRef] [PubMed] 
34. Kapsopoulou, K.; Kapaklis, A.; Spyropoulos, H. Growth and Fermentation Characteristics of a Strain of the Wine Yeast Kluyveromyces thermotolerans Isolated in Greece. World J. Microbiol. Biotechnol. 2005, 21, 1599-1602. [CrossRef]

35. Kapsopoulou, K.; Mourtzini, A.; Anthoulas, M.; Nerantzis, E. Biological Acidification during Grape must Fermentation using Mixed Cultures of Kluyveromyces thermotolerans and Saccharomyces cerevisiae. World J. Microbiol. Biotechnol. 2007, 23, 735-739. [CrossRef]

36. Gobbi, M.; Comitini, F.; Domizio, P.; Romani, C.; Lencioni, L.; Mannazzu, I.; Ciani, M. Lachancea thermotolerans and Saccharomyces cerevisiae in Simultaneous and Sequential Co-Fermentation: A Strategy to Enhance Acidity and Improve the overall Quality of Wine. Food Microbiol. 2013, 33, 271-281. [CrossRef] [PubMed]

37. Su, J.; Wang, T.; Wang, Y.; Li, Y.; Li, H. The use of Lactic Acid-Producing, Malic Acid-Producing, Or Malic Acid-Degrading Yeast Strains for Acidity Adjustment in the Wine Industry. Appl. Microbiol. Biotechnol. 2014, 98, 2395-2413. [CrossRef] [PubMed]

38. Snow, P.G.; Gallander, J.F. Deacidification of White Table Wines through Partial Fermentation with Schizosaccharomyces pombe. Am. J. Enol. Vitic. 1979, 30, 45-48.

39. Unterholzner, O.; Aurich, M.; Platter, K. Geschmacks Und Geruchsfehler Bei Rotweinen Verursacht Durch Schizosaccharomyces pombe L. Mitteilungen Klosterneuburg, Rebe Und Wein. Obstbau und Früchteverwertung 1988, $38,66-70$.

40. Yokotsuka, K.; Otaki, A.; Naitoh, A.; Tanaka, H. Controlled Simultaneous Deacidification and Alcohol Fermentation of a High-Acid Grape must using Two Immobilized Yeasts, Schizosaccharomyces pombe and Saccharomyces cerevisiae. Am. J. Enol. Vitic. 1993, 44, 371-377.

41. Pitt, J.I.; Ailsa, D. Yeasts. In Fungi and Food Spoilage, 1st ed.; Pitt, J.I., Hocking, A.D., Eds.; Springer: Berlin, Germany, 2009; pp. 357-382.

42. Benito, S.; Palomero, F.; Calderón, F.; Palmero, D.; Suárez-Lépe, J. Selection of Appropriate Schizosaccharomyces Strains for Winemaking. Food Microbiol. 2014, 42, 218-224. [CrossRef] [PubMed]

43. Benito, S.; Gálvez, L.; Palomero, F.; Morata, A.; Palmero, D.; Suarez-Lepe, J.A. Schizosaccharomyces Selective Differential Media. Afr. J. Microbiol. Res. 2013, 7, 3026-3036.

44. Jeffares, D.C.; Rallis, C.; Rieux, A.; Speed, D.; Převorovský, M.; Mourier, T.; Marsellach, F.X.; Iqbal, Z.; Lau, W.; Cheng, T.M. The Genomic and Phenotypic Diversity of Schizosaccharomyces Pombe. Nat. Genet. 2015, 47, 235-241. [CrossRef] [PubMed]

45. Comitini, F.; Gobbi, M.; Domizio, P.; Romani, C.; Lencioni, L.; Mannazzu, I.; Ciani, M. Selected Non-Saccharomyces Wine Yeasts in Controlled Multistarter Fermentations with Saccharomyces cerevisiae. Food Microbiol. 2011, 28, 873-882. [CrossRef] [PubMed]

46. Jolly, J.; Augustyn, O.; Pretorius, I. The Role and use of Non-Saccharomyces Yeasts in Wine Production. South Afr. J. Enol. Viticult. 2006, 27, 15-39.

47. Benito, S.; Hofmann, T.; Laier, M.; Lochbühler, B.; Schüttler, A.; Ebert, K.; Fritsch, S.; Röcker, J.; Rauhut, D. Effect on Quality and Composition of Riesling Wines Fermented by Sequential Inoculation with Non-Saccharomyces and Saccharomyces cerevisiae. Eur. Food Res. Technol. 2015, 241, 707-717. [CrossRef]

48. Benito, S.; Morata, A.; Palomero, F.; Gonzalez, M.; Suárez-Lepe, J. Formation of Vinylphenolic Pyranoanthocyanins by Saccharomyces cerevisiae and Pichia guillermondii in Red Wines Produced Following Different Fermentation Strategies. Food Chem. 2011, 124, 15-23. [CrossRef]

49. Bonciani, T.; Solieri, L.; de Vero, L.; Giudici, P. Improved Wine Yeasts by Direct Mating and Selection under Stressful Fermentative Conditions. Eur. Food Res. Technol. 2016, 242, 899-910. [CrossRef]

50. García, M.; Greetham, D.; Wimalasena, T.T.; Phister, T.G.; Cabellos, J.M.; Arroyo, T. The Phenotypic Characterization of Yeast Strains to Stresses Inherent to Wine Fermentation in Warm Climates. J. Appl. Microbiol. 2016, 121, 215-233. [CrossRef] [PubMed]

51. Kutyna, D.R.; Varela, C.; Henschke, P.A.; Chambers, P.J.; Stanley, G.A. Microbiological Approaches to Lowering Ethanol Concentration in Wine. Trends Food Sci. Technol. 2010, 21, 293-302. [CrossRef]

52. Gobbi, M.; de Vero, L.; Solieri, L.; Comitini, F.; Oro, L.; Giudici, P.; Ciani, M. Fermentative Aptitude of Non-Saccharomyces Wine Yeast for Reduction in the Ethanol Content in Wine. Eur. Food Res. Technol. 2014, 239, 41-48. [CrossRef]

53. Benito, S.; Palomero, F.; Morata, A.; Calderon, F.; Palmero, D.; Suarez-Lepe, J. Physiological Features of Schizosaccharomyces pombe of Interest in Making of White Wines. Eur. Food Res. Technol. 2013, 236, 29-36. [CrossRef] 
54. Röcker, J.; Strub, S.; Ebert, K.; Grossmann, M. Usage of Different Aerobic Non-Saccharomyces Yeasts and Experimental Conditions as a Tool for Reducing the Potential Ethanol Content in Wines. Eur. Food Res. Technol. 2016, 242, 2051-2070. [CrossRef]

55. Contreras, A.; Hidalgo, C.; Henschke, P.A.; Chambers, P.J.; Curtin, C.; Varela, C. Evaluation of Non-Sacharomyces Yeasts for the Reduction of Alcohol Content in Wine. Appl. Environ. Microbiol. 2014, 80, 1670-1678. [CrossRef] [PubMed]

56. Ciani, M.; Morales, P.; Comitini, F.; Tronchoni, J.; Canonico, L.; Curiel, J.A.; Oro, L.; Rodrigues, A.J.; Gonzalez, R. Non-Conventional Yeast Species for Lowering Ethanol Content of Wines. Front. Microbiol. 2016, 7. [CrossRef] [PubMed]

57. Contreras, A.; Curtin, C.; Varela, C. Yeast Population Dynamics Reveal a Potential 'collaboration' between Metschnikowia pulcherrima and Saccharomyces uvarum for the Production of Reduced Alcohol Wines during Shiraz Fermentation. Appl. Microbiol. Biotechnol. 2015, 99, 1885-1895. [CrossRef] [PubMed]

58. Morales, P.; Rojas, V.; Quirós, M.; Gonzalez, R. The Impact of Oxygen on the Final Alcohol Content of Wine Fermented by a Mixed Starter Culture. Appl. Microbiol. Biotechnol. 2015, 99, 3993-4003. [CrossRef] [PubMed]

59. Röcker, J.; Schmitt, M.; Pasch, L.; Ebert, K.; Grossmann, M. The use of Glucose Oxidase and Catalase for the Enzymatic Reduction of the Potential Ethanol Content in Wine. Food Chem. 2016, 210, 660-670. [CrossRef] [PubMed]

60. Deák, T. Yeasts. In Handbook of Food Spoilage, 2nd ed.; Deák, T., Ed.; CRC press: New York, NY, USA, 2007; pp. 294-296.

61. Xia, C.; Hong, M.; YunFeng, Z.; YongNing, W. Research Progress on Toxicity and Contamination of Ethyl Carbamate in Fermented Foods. J. Food Saf. Qual. 2014, 5, 2617-2622.

62. Shimazu, Y.; Uehara, M.; Watanabe, M. Transformation of Citric Acid to Acetic Acid, Acetoin and Diacetyl by Wine Making Lactic Acid Bacteria. Agric. Biol. Chem. 1985, 49, 2147-2157. [CrossRef]

63. Clemente-Jimenez, J.M.; Mingorance-Cazorla, L.; Martínez-Rodríguez, S.; Las Heras-Vázquez, F.J.; Rodríguez-Vico, F. Molecular Characterization and Oenological Properties of Wine Yeasts Isolated during Spontaneous Fermentation of Six Varieties of Grape Must. Food Microbiol. 2004, 21, 149-155. [CrossRef]

64. Parapouli, M.; Hatziloukas, E.; Drainas, C.; Perisynakis, A. The Effect of Debina Grapevine Indigenous Yeast Strains of Metschnikowia and Saccharomyces on Wine Flavour. J. Ind. Microbiol. Biotechnol. 2010, 37, 85-93. [CrossRef] [PubMed]

65. Romano, P.; Suzzi, G.; Comi, G.; Zironi, R. Higher Alcohol and Acetic Acid Production by Apiculate Wine Yeasts. J. Appl. Bacteriol. 1992, 73, 126-130. [CrossRef]

66. Romano, P.; Suzzi, G. Higher Alcohol and Acetoin Production by Zygosaccharomyces Wine Yeasts. J. Appl. Bacteriol. 1993, 75, 541-545. [CrossRef]

67. Pozo-Bayón, M.; G-Alegría, E.; Polo, M.; Tenorio, C.; Martín-Álvarez, P.; Calvo De La Banda, M.T.; Ruiz-Larrea, F.; Moreno-Arribas, M. Wine Volatile and Amino Acid Composition After Malolactic Fermentation: Effect of Oenococcus oeni and Lactobacillus plantarum Starter Cultures. J. Agric. Food Chem. 2005, 53, 8729-8735. [CrossRef] [PubMed]

68. Maynard, L.S.; Schenker, V.J. Monoamine Oxidase Inhibition by Ethanol in Vitro. Nature 1962, 575-576. [CrossRef]

69. Kanny, G.; Gerbaux, V.; Olszewski, A.; Frémont, S.; Empereur, F.; Nabet, F.; Cabanis, J.; Moneret-Vautrin, D. No Correlation between Wine Intolerance and Histamine Content of Wine. J. Allergy Clin. Immunol. 2001, 107, 375-378. [CrossRef] [PubMed]

70. Jansen, S.C.; van Dusseldorp, M.; Bottema, K.C.; Dubois, A.E. Intolerance to Dietary Biogenic Amines: A Review. Ann. Allergy Asthma Immunol. 2003, 91, 233-241. [CrossRef]

71. Moreno-Arribas, M.V.; Polo, M.C. Occurrence of Lactic Acid Bacteria and Biogenic Amines in Biologically Aged Wines. Food Microbiol. 2008, 25, 875-881. [CrossRef] [PubMed]

72. Lehtonen, P. Determination of Amines and Amino Acids in Wine-A Review. Am. J. Enol. Vitic. 1996, 47, 127-133.

73. Medina, K.; Boido, E.; Fariña, L.; Gioia, O.; Gomez, M.; Barquet, M.; Gaggero, C.; Dellacassa, E.; Carrau, F. Increased Flavour Diversity of Chardonnay Wines by Spontaneous Fermentation and Co-Fermentation with Hanseniaspora vineae. Food Chem. 2013, 141, 2513-2521. [CrossRef] [PubMed] 
74. Alcaide-Hidalgo, J.M.; Moreno-Arribas, M.V.; Martín-Álvarez, P.J.; Polo, M.C. Influence of Malolactic Fermentation, Postfermentative Treatments and Ageing with Lees on Nitrogen Compounds of Red Wines. Food Chem. 2007, 103, 572-581. [CrossRef]

75. Smit, A.Y.; du Toit, M. Evaluating the Influence of Malolactic Fermentation Inoculation Practices and Ageing on Lees on Biogenic Amine Production in Wine. Food Bioprocess Technol. 2013, 6, 198-206. [CrossRef]

76. Sumby, K.M.; Grbin, P.R.; Jiranek, V. Implications of New Research and Technologies for Malolactic Fermentation in Wine. Appl. Microbiol. Biotechnol. 2014, 98, 8111-8132. [CrossRef] [PubMed]

77. Belda, I.; Navascués, E.; Marquina, D.; Santos, A.; Calderón, F.; Benito, S. Outlining the Influence of Non-conventional Yeasts in Wine Ageing Over Lees. Yeast 2016, 33, 329-338. [CrossRef] [PubMed]

78. Domizio, P.; Liu, Y.; Bisson, L.; Barile, D. Cell Wall Polysaccharides Released during the Alcoholic Fermentation by Schizosaccharomyces pombe and S. Japonicus: Quantification and Characterization. Food Microbiol. 2017, 61, 136-149. [CrossRef] [PubMed]

79. Ribereau-Gayon, P.; Glories, Y.; Maujean, A.; Dubourdieu, D.; Ribéreau-Gayon, P.; Glories, Y.; Maujean, A.; Dubourdieu, D. The chemistry of wine stabilization and treatments. In Handbook of Enology, 2nd ed.; Ribereau-Gayon, P., Ed.; Wiley: West Sussex, UK, 2006; pp. 141-203.

80. Morris, E.; Eddy, A. Method for the Measurement of Wild Yeast Infection in Pitching Yeast. J. Inst. Brewing 1957, 63, 34-35. [CrossRef]

81. Vaughnan-Martini, A.; Martini, A. Determination of Ethanol Production. In The Yeast. A Taxonomic Study; Elsevier: Amsterdam, The Netherlands, 1999; p. 107.

82. Kurtzman, C.P.; Fell, J.W.; Boekhout, T.; Robert, V. Methods for isolation, phenotypic characterization and maintenance of yeasts. In The Yeasts, a Taxonomic Study, 5th ed.; Kurtzman, C.P., Fell, J.W., Boekhout, T., Eds.; Elsevier: Amsterdam, The Netherlands, 2011; pp. 87-110.

Sample Availability: Samples of the compounds are available from the authors.

(C) 2016 by the authors; licensee MDPI, Basel, Switzerland. This article is an open access article distributed under the terms and conditions of the Creative Commons Attribution (CC-BY) license (http://creativecommons.org/licenses/by/4.0/). 